\title{
Eifred Markussen
}

Forsker, Nordisk institutt for studier av innovasjon, forskning og utdanning (NIFU)

\author{
Artikkelgruppe om skolereformen Kunnskapsløftet \\ Setteredaktører for artikkelgruppen: \\ Therese Nerheim Hopfenbeck, Post doktor, \\ Institutt for lærerutdanning og skoleforskning, \\ Universitetet i Oslo \\ Sølvi Lillejord, Instituttleder, \\ Institutt for lærerutdanning og skoleforskning, \\ Universitetet i Oslo
}

\section{Spesialundervisning i videregående opplæring fra Reform 94 til Kunnskapsløftet ${ }^{1}$}

\begin{abstract}
Sammendrag
Artikkelen drøfter praktisering og resultater av spesialundervisning i videregående opplæring i Norge med hovedfokus på tiden fra innføringen av Reform 94 til like etter innføringen av Kunnskapsløftet. Artikkelen drøfter forholdet mellom segregerte og inkluderende løsninger, men uten å ha som ambisjon å svare på spørsmålet om hva som er best. Det vises at selv om inkludering som prinsipp har bred politisk oppslutning, foregår det fortsatt omfattende bruk av segregerende tiltak i spesialundervisningen. Kvantitativ forskning i perioden 1994-2009 viser at elevene oppnår best faglige resultater når de får spesialundervisning i inkluderende løsninger, og at elever som får spesialundervisning i egne klasser med redusert elevtall i gjennomsnitt oppnår de svakeste faglige resultatene. Kvalitativ forskning modererer disse funnene, og viser at det også er mulig å oppnå gode resultater innenfor segregerte løsninger. Dette skjer scrlig når to forutsetninger er tilstede, at skolens ledelse og personale har et gjennomtenkt og bevisst forhold til sin pedagogikk, og når ungdommene får tett oppfølging.
\end{abstract}

\section{Innledning}

I denne artikkelen skal vi drøfte praktisering og resultater av spesialundervisning i videregående opplæring i Norge. Hovedfokus vil være de siste 15 årene, perioden fra innføringen av Reform 94 og til like etter innføringen av Kunnskapsløftet, men vi vil også, fordi vi mener det er viktig å studere og drøfte spesialundervisning innefor en kontekst, se det hele i et nærhistorisk perspektiv ved å trekke noen linjer tilbake til midten av 1960-tallet.

Opplæringslova formulerer hva som skal til for at en elev skal få spesialundervisning. "Elevar som ikkje har eller som ikkje kan få tilfredsstillande utbytte av det ordinære opplæringstilbodet, har rett til spesialundervisning” (§ 5- 
1). Når den ordinære opplæringen ikke klarer å gi et tilfredsstillende tilbud, kompenserer samfunnet ved å sette inn ekstra tiltak i form av spesialundervisning. I norsk spesialundervisning har de viktigste virkemidlene vært tilrettelagte læremidler, bygningsmessige tilpasninger, ekstra lærere, lærere med spesiell kompetanse, assistenter, enetimer, smågrupper eller ekstra timer.

Målet med spesialundervisningen er å minke forskjeller i utbytte av undervisning. Gjennom å behandle elevene ulikt er målet å oppnå større grad av likhet, ressursulikhet skal bidra til større grad av resultatlikhet. Spesialundervisningen bærer i seg en ambisjon om å redusere forskjeller og bidra til utjevning.

For å nå dette målet har man i stor grad gitt spesialundervisning innenfor segregerte løsninger. Etter hvert har det blitt et økende fokus på å ta i bruk inkluderende løsninger. Vi vil i denne artikkelen drøfte forholdet mellom segregerte og inkluderende løsninger innenfor spesialundervisningen, men uten å ha som ambisjon å svare på spørsmålet om hva som er best. Vi vil imidlertid peke på forhold som, basert på omfattende forskning gjennom 15 år, etter vår vurdering er sentrale for å gi flere et bedre utbytte av spesialundervisning i videregående opplæring.

\section{Sentrale styringssignaler for spesialundervisning i videregående} opplæring gjennom 45 år

Selv om hovedfokus i denne artikkelen er perioden fra innføringen av Reform 94 til like etter innføringen av Kunnskapsløftet, er det viktig å studere og drøfte spesialundervisningen innefor en bredere historisk kontekst. Utviklingen i årene før Reform 94 er også viktig for å forstå det som skjedde under Reform 94 og under innføringen av Kunnskapsløftet. Derfor skal vi nå se nærmere på hvordan intensjonene for og reguleringen av spesialundervisningen endret seg fra midt på 1960-tallet frem til innføringen av Kunnskapsløftet ${ }^{2}$.

Midt på 1960-tallet var segregeringstanken rådende innenfor spesialundervisningen. Det var planlagt en omfattende utbygging av spesialskolene (St.meld. nr. 42 1965-66), men denne fant aldri sted. Én forklaring er at man var inne i en ideologisk brytningstid. Nye ideer om hvordan spesialundervisning skulle gjennomføres var på vei inn. Et uttrykk for de nye tankene var oppnevnelsen av Steen-komiteen (skolekomiteen) i august 1965.

Allerede på slutten av 1960-tallet ble prinsippet om en opplæring tilpasset den enkeltes forutsetninger formulert av Steen-komiteen: "Skolene og undervisningen må ordnes slik at den enkelte får starte i den videregående skolen på det nivå vedkommende har nådd fram til ved avslutningen av 9-årig folkeskole, og undervisningen må til en hver tid - så langt det er praktisk mulig - tilpasses den enkeltes særlige forutsetninger med hensyn til evner og anlegg, arbeidskraft og standpunkt” (Innstilling I:13). 
Etter et omfattende utrednings- og meldingsarbeid (bl.a. Steen-komiteen tre innstillinger 1967, 1969 og 1970, Kyrkje- og undervisningsdepartementet 1967 og St.meld. nr 91, 1969-70), ble den nye videregående opplæring etablert fra 1.august 1976. Det ble innført rett til spesialundervisning for ungdom som var elever og som hadde behov for dette (Lov om videregående opplæring, 1974, $\S 11,1$. ledd). Ambisjonen var å skape et likeverdig skoletilbud for all ungdom. Men det var ikke plass til alle som ville inn i videregående opplæring. Konsekvensen ble at mange unge med behov for spesialundervisning ikke kom inn. De hadde svakest karakterer, tapte i konkurransen om plassene, og ble til tross for innføring av fortrinnsrett til inntak i 1987, ofte stående i kø (Aarnes 1987).

Situasjonen forble uendret frem til Reform 94 ble iverksatt fra og med skoleåret 1994-95. (NOU 1991:4, St.meld. nr. 33 (1991-92), Innst.S. nr. 200 (1991-92), Ot.prp. nr. 31 (1992-93), Innst.O. nr. 80 (1992-93), Besl.O. nr. 93 (1992-93)). Reform 94 var ikke en reform for spesialundervisning, men ble innført av helt andre årsaker. Likevel fikk reformen stor betydning for unge med spesialundervisning. Reform 94 åpnet dørene for alle som hadde gjennomført ungdomsskolen, og dermed kunne ungdom med behov for spesialundervisning, som ellers ikke ville kommet inn, begynne i videregående opplæring på lik linje med alle andre. I tillegg fikk disse ungdommene noen særretter bl.a. ved retten til primært valgt grunnkurs og at de kunne få bruke lengre tid enn andre, inntil fem år (Lov om videregående opplæring §8). Reform 94 ble et rettighetssprang for elever med behov for spesialundervisning.

Som en oppfølging av NOU 1995: 18, vedtok Stortinget i juni 1998 den nye Opplæringslova (Besl. O. nr. 68 1997-98). To sentrale elementer hadde betydning for unge med behov for spesialundervisning. For det første ble prinsippet om tilpasset opplæring tatt inn i lovens formålsparagraf. Begrunnelsen for dette var at opplæringen skal tilpasses ut fra den enkeltes forutsetning, og at behov for spesialundervisning først oppstår når denne ordinære tilpassede opplæringen ikke gir eleven et tilfredsstillende læringsutbytte. For det andre ble individuell opplæringsplan for barn og unge med spesialundervisning vedtatt. Med denne bestemmelsen ønsket man å sikre at elevene, ved avvik fra de ordinære læreplanene som skulle ligge til grunn, skulle sikres et godt tilbud.

I juni 2003 ble NOU 2003:16, I første rekke lagt frem. På grunnlag av formuleringen om tilpasset opplæring i formålsparagrafen, lanserte utvalget en ambisiøs målsetting. De ønsket å ”(...) klargjøre hva som skal til for å ta inkluderingsbegrepet på alvor, både sosialt, faglig og kulturelt, ved å kreve tilpasset opplæring for alle, ment som alle” (s 84). Utvalget definerte inkludering som "utvikling av skolen med det formål at den skal passe hele den menneskelige variasjonen" (s 84), i motsetning til integrering som handler om plassering basert på diagnose. Det ble poengtert at inkludering gjelder alle, ikke alle med særlige behov (s 87). NOU'en understreket at inkludering handler om å tilpasse skolen til elevmassen, slik at den kan gi et tilpasset opplæringstilbud til alle. Ut- 
valget påpekte at god tilpasset opplæring vil gi flere opplæring i tråd med evner og forutsetninger, og dermed redusere behovet for spesialundervisning (s 86).

På grunnlag av en gjennomgang av forskning om spesialundervisning i norsk grunnskole og videregående opplæring, skrev utvalget ”... at det er vanskelig å påvise at spesialundervisning $\mathrm{i}$ sin nåværende form samlet sett har noen stor effekt” (NOU 2003:16:95).

Utvalget argumenterte for at i en skole hvor inkluderingen gjelder alle og alle får tilpasset opplæring i tråd med sine forutsetninger, vil alle elever få dekket sine opplæringsbehov og ha mulighet for å oppnå godt utbytte av undervisningen. Utvalget konkluderte at i en slik skole vil det ikke være behov for spesialundervisning, og forslo at retten til spesialundervisning ble fjernet fra Opplæringslova, kombinert med en sterkere satsing på tilpasset opplæring: "Kravet om tilpasset opplæring for alle etter opplæringslovens bestemmelser forsterkes (§1-2), og nåværende bestemmelser om spesialundervisning utgår” (NOU 2003:16: 83).

Da departementet foreslo Kunnskapsløftet, ble ikke denne delen av I første rekke videreført, verken i Kultur for laring (St.meld. nr. 30 2003-2004) eller i forslag til endringer i Opplæringslova (Ot.prp. nr. 57 2004-2005). Selv om Regjeringen så at eksisterende spesialundervisning ikke fungerte etter intensjonene, og argumenterte for en sterkere satsing på tilpasset opplæring, ble konklusjonen å gå inn for å "videreføre prinsippene i dagens bestemmelser om tilpasset opplæring og spesialundervisning” (St.meld. nr. 30 2003-2004:87). Hovedargumentet var ikke av pedagogisk, men av juridisk, rettssikkerhetsmessig og økonomisk art. Uten bestemmelsene om spesialundervisning fryktet man at de unges rettigheter til spesialundervisning skulle svekkes og at kommuner og fylkeskommuner ville bruke mindre penger til spesialundervisning ute i skolene.

Stortinget var enig med Regjeringen, og da Kunnskapsløftet ble behandlet i Stortinget 4.juni 2005, ble det ikke foretatt noen endringer i $\S 5$ Spesialundervisning ${ }^{3}$. Resultatet ble at Kunnskapsløftet ikke medførte noen formelle, juridiske endringer når det gjaldt spesialundervisning i grunnopplæringen.

Samtidig sa Regjeringen: "Det er imidlertid et klart mål at spesialundervisning skal være nødvendig for en lavere andel elever enn hva tilfellet er i dag. Samtidig er det behov for å bedre kvaliteten på den spesialundervisning som gis. Det er også viktig at skoleeier vurderer modellene for tildeling av ressurser til skolene i lys av målet om en bedre tilpasset opplæring for alle elevene” (St.meld. nr.30. 2003-2004:87).

Og Stortinget sa det slik: "Komiteen er enig i at det er nødvendig å styrke den tilpassede opplæringen, slik at alle sider av læringsmiljøet tar hensyn til variasjonene i elevenes forutsetninger og behov. (...) det må arbeides målrettet for å redusere bruken av (...) [spesialundervisningen]” (Innst.S.nr.268 20032004:37). 
Vi ser altså at samtidig som Kunnskapsløftet ikke medførte noen endringer av spesialundervisningen, sendte sentrale myndigheter, Regjering og Storting, ut signaler om at de ønsket en utvikling i tråd med tenkningen til I første rekke: mindre spesialundervisning og mer tilpasset opplæring. På denne måten ble det sendt doble signaler ut til skoler og pedagoger: Fortsett som før, men vi vil ha mindre spesialundervisning.

Konsekvensen av uklare signaler kan være at aktørene i praksisfeltet opplever at de kan velge praksis selv. Sentrale styringssignaler kan legitimere uendret praksis i spesialundervisning, men også en endring i retning mer inkludering. Også Jenssen \& Lillejord (2009) observerer det samme i en studie av tilpasset opplæring; uklare styringssignaler fører til uensartet praksis.

\section{Spesialundervisning - avgrensning av begrepet}

Egentlig skulle det være lett å definere begrepet spesialundervisning. Opplæringslova avgrenser begrepet for oss. Spesialundervisning er et opplæringstilbud som gis etter enkeltvedtak (§ 5-1, § 5-3), og kriteriet for å få spesialundervisning er at eleven ikke har eller ikke kan få tilfredsstillende utbytte av det ordincere opplceringstilbudet (§ 5-1). For at det skal kunne gjøres et enkeltvedtak om spesialundervisning skal det foreligge en sakkyndig vurdering (§ 5-3). Loven krever også at elever som har spesialundervisning skal ha en individuell opplceringsplan (IOP) (§ 5-5). Det er altså fire elementer, uthevet over, som avgrenser fenomenet spesialundervisning juridisk.

Vi merker oss at det er kvaliteten på opplæringstilbudet i forhold til elevens forutsetninger som skal utløse spesialundervisning, ikke elevens forutsetninger alene. Her anlegges et relasjonelt og kontekstuelt og ikke et medisinsk eller kategorisk perspektiv på spesialundervisning (Skrtic 1991, OECD 1999, Ainscow 1999, Hausstätter 2007, Nordahl og Sunnevåg 2008). Dette betyr, streng tatt, at en elevs behov for spesialundervisning kan endre seg når opplæringssituasjonen endres, dvs. fra fag til fag, fra klasse til klasse, fra lærer til lærer, fra skole til skole eller fra utdanningsprogram til utdanningsprogram.

Selv om den juridiske avgrensningen av spesialundervisning dermed skulle kunne brukes for å bestemme hvilke elever i en klasse eller på en skole som har spesialundervisning, så er ikke virkeligheten så enkel. Når man går ut i norske klasser og spør lærerne hvem i klassene som har spesialundervisning, er det svært ofte ikke den juridiske avgrensningen som anvendes. I en rekke undersøkelser hvor lærere har fått dette spørsmålet, identifiserer de elever uten enkeltvedtak som elever med spesialundervisning, mens noen elever med enkeltvedtak ikke pekes ut som elever med spesialundervisning (Grøgaard, Hatlevik og Markussen 2004, Markussen 2000, 2001, 2004, Markussen m.fl. 2003, Markussen m.fl. 2009).

Dette kan nok forklares med at mange lærere i sitt daglige virke er mer opptatt av hva som skjer i eget klasserom og med egne elever enn av den 
juridiske avgrensningen av begrepet spesialundervisning. De ser på hva som skjer på læringsarenaen, og når de skal plukke ut de som har spesialundervisning, gjør de det på et praktisk, pedagogisk grunnlag. Dersom de ut fra den ekstra hjelpen og støtten en elev får vurderer at dette er spesialundervisning, da er det spesialundervisning, enkeltvedtak eller ikke.

Når vi i denne artikkelen bruker begrepet spesialundervisning, legger vi til grunn både en juridisk og en pedagogisk forståelse. Det betyr at også elever som ikke har spesialundervisning i juridisk forstand, men som inkluderes blant de som har spesialundervisning når de selv og/eller læreren deres mener at de har det.

En inkluderende skole - hva betyr det?

Da begrepet inkludering ble introdusert, ble dette av mange oppfattet og forstått som et nytt ord for og synonymt med integrering, og det handlet fortsatt om hvordan undervisningen skulle organiseres, hvor elevene med spesialundervisning skulle plasseres; i klassen eller utenfor (Antia, Stinson \& Gaustad 2002). Innholdet i begrepet utviklet seg imidlertid, og handlet ikke lenger bare om plassering av elever med spesialundervisning i ordinære klasser (Skrtic, Sailor \& Gee 1996, Topping \& Maloney 2005). Dyson, Howes \& Roberts (2003), sier at inkludering handler om "increasing the participation of all students in the broad social and academic life of regular schools" (s 283). Fokus er at skolen må endre seg og tilpasse seg elevmassen, og gi dem et tilbud i tråd med deres forutsetninger, fokus er ikke på elevens vanske.

En inkluderende skole betyr en systemendring (Dyson, Howes \& Roberts 2003, Mitchell 2004). "(...) it is about a paradigm shift which has implications for the ways schools are organized, the way teachers teach, and for the values which underpin the whole education system” (Dyson og Millward 1997: 54). Det handler om en helt ny måte å tenke undervisning og læring på.

I Norge ble begrepet inkludering første gang introdusert med L97, og også her ble det oppfattet som et nytt ord som skulle erstatte integreringsbegrepet. Og akkurat som i den internasjonale debatten endret begrepet innhold. I første rekke la vekt på den inkluderende skolen: ”Inkludering handler i første rekke om miljøet. Det er et program for utvikling av skolen med det formål at den skal passe hele den menneskelige variasjon" (NOU 2003:16: 84).

Begrepet inkludering og inkluderende skole må i dag forstås som en skole for alle, en skole som skal tilpasse seg variasjon i hele elevmassen og som kan tilby alle en opplæring i tråd med den enkeltes forutsetninger, en skole som praktiserer tilpasset opplæring. 
Hva sier den internasjonale litteraturen?

Samtidig som det altså skjedde et skifte i tenkningen omkring spesialundervisning i Norge midt på 60-tallet fant noe tilsvarende sted innenfor internasjonal forskning og debatt om spesialundervisning. Dunn (1968) argumenterte for at det forelå forskningsresultater som viste at elever med lærevansker profiterte på å få gå i ordinære klasser fremfor i segregerte løsninger: "(...) retarded pupils make as much or more progress in the regular grades as they do in special education” (Dunn 1968: 8). Siden Dunn startet denne debatten er det gjennomført flere rekke forskningsprosjekter og en rekke metastudier for å forsøke å besvare spørsmålet: Hva er best, segregering eller integrering/inkludering?

Mange av disse studiene konkluderte med at inkludering og læringsarbeid i et elevfellesskap sammen med jevnaldrende gir best resultat, så vel faglig som sosialt (Jenkinson 1997, Gartner \& Lipsky 1996, Baker, Wang \&Walberg 1994). I en studie av inclusive education i USA, Canada og Australia og fem europeiske land gjennomført av OECD i perioden 1995-1998 konkluderes det med at: "(...) all children, however heavily disabled, can be included in regular schools with no detriment to themselves or other pupils, providing the conditions are right" (OECD 1999: 49).

Andre studier konkluderte motsatt (Fuchs \& Fuchs 1994, Hallahan \& Kaufmann 1994/1995). I boka The Illusion of Full Inclusion, argumenterer Hallahan \& Kaufmann (1994/1995) for at det er nødvendig med "a special, supplementary structure (...) to keep many students with special needs from dropping through the floor of public education” (Hallahan \& Kaufmann 1994:ix$\mathrm{x})$. De argumenterte også for at selv om forskning kunne dokumentere fordeler med å gå i ordinære klasser, så kunne dette kanskje "(...) justify the reduction in the number of special classes, but not their elimination" (Hallahan \& Kaufmann 1994:ix-x). Dette standpunktet har de holdt fast ved (Kaufmann \& Sasso 2006a,b).

Et klassisk argument i denne debatten har vært hensynet til de ordinære elevene, og et synspunkt som har vært fremmet er at de vil tape på å gå i klasser med elever med spesialundervisning. Flere arbeider avviser dette (Staub \& Peck 1994, Gartner \& Lipsky 1996, 1999, Salend \& Duhaney 1999), og det konkluderes med at "the placement of students without disabilities in inclusion programs does not appear to interfere with their academic performance and has several social benefits for these students” (Salend \& Duhaney 1999: 488).

Mens noen metastudier konkluderer med at inkludering gir best læringsresultater, og andre anbefaler at segregering må være mulig, konkluderer andre meta-analyser igjen med at forskningen ikke kan gi svar på om segregering eller integrering/inkludering gir best resultater. Resultatene spriker (Hegarty 1989, Salend \& Duhaney 1999, Lindsay 2003): ”In summary, the studies reviewed reveal that the impact of placement in inclusive settings on academic and social performance (...) has been varied” (Salend \& Duhaney 1999: 497). 
Dette betyr at motsetningene og uenigheten fortsatt fins. For å illustrere dette refereres Cigman (2007) som viser at det fins tre posisjoner i debatten i England. For det første er det de som går inn for at alle spesialskoler skal stenges og at alle barn skal få sin utdanning i ordinære skoler (Low 2007). For det andre er det en mer moderat posisjon som sier noen der den radikale posisjonen sier alle. De mener at så få som mulig skal gå i segregerte løsninger, men om noen ønsker det skal det være mulig (Low 2007). For det tredje er det den inkluderende posisjonen (Cigman 2007, Norwich 2007, Ainscow 2007). De fokuserer på den ordinære skolen og argumenterer for at denne må tilpasse seg hele variasjonen i elevmassen. "This philosophy is based on a simple idea: That schools should adapt to the diverse needs of children. (...). It conceptualises children as different from each other in all sorts of ways, and adresses these differences as a matter of priority” (Cigman 2007: xix). Målet er å forbedre den ordinære skolen slik at den "can meet the needs of all children, while offering them similar rights and opportunities" (Ainscow 2007: 129).

Etter å ha lest mye av den internasjonale litteraturen på området er jeg tilbøyelig til å være enig med de som sier at den internasjonale forskningen så langt ikke gir entydige svar på hva som er beste måten å organisere spesialundervisning på.

Hva sier norsk forskning om spesialundervisning i videregående opplæring?

Dette avsnittet bygger på fem sentrale forskningsprosjekter omkring spesialundervisning i videregående opplæring gjennomført i Norge i perioden 19942009.

For det første, en kvantitativ, longitudinell studie som fulgte noen elever med spesialundervisning i det første Reform 94-kullet gjennom fem år i videregående opplæring fra høsten 1994 til våren 1999. Studien ble rapportert i Fafo-rapporten Scrskilt tilrettelagt opplæring i videregående - hjelper det? i 2000 (Markussen 2000).

For det andre, Møreforsknings evaluering av spesialundervisning innenfor evalueringen av Reform 94. Dette var et prosjekt med et longitudinelt design som kombinerte kvantitative og kvalitative data. Studien ble rapportert i flere delrapporter og i sluttrapporten Innestenging, utestenging eller inkludering? (Kvalsund \& Myklebust 1998).

For det tredje, en kvantitativ studie med longitudinelt design som fulgte et stort utvalg elever fra det andre Reform 94-kullet gjennom tre år i videregående opplæring. Studien inngikk i Fafos evaluering av Oppfølgingstjenesten under Reform 94, og er rapportert i et Fafo-notat (Grøgaard 2000) og i en artikkel i Tidsskrift for ungdomsforskning: Integrerte eller segregerte undervisningsopplegg i videregående opplcering: Hvilke gir best resultater? (Grøgaard 2002). 
For det fjerde, en kvalitativ, longitudinell studie som fulgte 48 elever med spesialundervisning gjennom intervjuer med elever, lærere, skoleleder og foresatte, samt noe observasjon gjennom tre år i videregående opplæring fra høsten 2000 til våren 2003. Studien ble rapportert i NIFU-rapporten Høy pedagogisk bevissthet og tett oppfølging i 2003 (Markussen, Brandt \& Hatlevik 2003).

For det femte, en kombinert kvantitativ og kvalitativ studie av spesialundervisning like etter innføringen av Kunnskapsløftet. I den kvantitative delen ble noen elever med og uten spesialundervisning, deres lærere, rektorer og fylkesskolesjefer fulgt gjennom skoleåret 2007-2008. I den kvalitative delen ble 15 ungdommer med spesialundervisning etter enkeltvedtak fulgt gjennom to skoleår fra høsten 2006 til våren 2008. Studien ble rapportert i NIFU STEPrapporten Inkludert eller segregert? i 2009 (Markussen, Frøseth \& Grøgaard 2009).

De kvantitative undersøkelsene gjennomført under Reform 94 (Markussen 2000, Kvalsund \& Myklebust 1998 og Grøgaard 2002) og tidlig under Kunnskapsløftet (Markussen m.fl. 2009) viser bemerkelsesverdige like resultater. Både i det første Reform 94-kullet og i det første Kunnskapsløftet-kullet identifiseres utstrakt bruk av segregerende virkemidler. I undersøkelsen gjort blant elever i det første Reform 94-kullet fikk hver tredje spesialundervisningselev spesialundervisningen i egne klasser, og blant elever med spesialundervisning i ordinære klasser fikk to av tre deler av spesialundervisningen utenfor klassen i små grupper eller enetimer. Også Møreforsknings evaluering av Reform 94 fant at når elever med spesialundervisning får faglige vansker, er løsningen ofte at de får spesialundervisning utenfor klassen (Kvalsund \& Myklebust 1998). I det første Kunnskapsløftet-kullet fant man at i fagene norsk, engelsk og matematikk ble 25-30 prosent av spesialundervisningen gitt utenfor elevenes klasser som gruppeundervisning eller enetimer. Både evalueringen av Reform 94 og Kunnskapsløftet fant at det var flere gutter enn jenter som hadde spesialundervisning, at foreldrene til unge med spesialundervisning hadde lavere utdanning enn foreldrene til ordinære elever og at unge med spesialundervisning hadde betydelig svakere karakterer fra grunnskolen enn ordinære elever.

Hovedkonklusjonen fra forskning omkring både Reform 94 (Markussen 2000) og Kunnskapsløftet (Markussen m.fl. 2009) var at elever som får spesialundervisning i egne klasser med redusert elevtall oppnår dårligere resultater enn de elevene med spesialundervisning som går i egne klasser, alt annet likt. Det er viktig å presisere at denne effekten, samt de øvrige effektene identifisert i kvantitative analyser og som omtales nedenfor, er gjennomsnittseffekter. At elever i egne klasser presterer svakere er også i tråd med Møreforsknings evaluering av Reform 94 (Kvalsund \& Myklebust 1998), hvor det konkluderes med at støttetimen fungerer som utestenging fra kvalifiserende innhold. Også Grøgaard (2002) konkluderte på samme måte, og han forklarer bedre prestasjoner i ordinære klasser med at de unge får et faglig løft av det gjennomsnittlige prestasjonsnivået i klassen. 
Både Markussen (2000), Grøgaard (2000, 2002) og Markussen m.fl. (2009) fant også at når elevene med spesialundervisning hadde tilhørighet til ordinære klasser, spiller det ingen rolle for prestasjonsnivået og kompetanseoppnåelsen om de har deler av spesialundervisningen sin utenfor klassene i form av enetimer og grupper, eller om de har all spesialundervisning inne i klassen, bl.a. i form av tolærersystem eller med assistent. Det ser ut til at det som teller er å ha en fot innenfor det ordinære klassefellesskapet.

Disse undersøkelsene fant også at det som hadde sterkest betydning for elevenes resultater, var den enkeltes egne ressurser, målt med karakterene deres fra tiende klasse i grunnskolen, alt annet likt.

Et klassisk argument mot at elever med spesialundervisning skal ha tilhørighet til ordinære klasser har vært at dette går ut over de andre elevene, de taper faglig på inkludering. To undersøkelser har sett på dette. Både Grøgaard (2002) og Markussen m.fl. (2009) konkluderte at de ordinære elevene tjener på å gå i klasser med elever med spesialundervisning.

Undersøkelsen fra 2009 presiserte at dette var en effekt av det samlede prestasjonsnivået i yrkesfagklassene på de enkeltes prestasjoner. Når det gjennomsnittlige nivået i disse klassene steg, klarte elevene seg bedre, og når det gjennomsnittelige nivået sank, gjorde elevene det dårligere. Dette betyr at det ikke kan være for mange elever med spesialundervisning i klassene, da synker det gjennomsnittelige faglige nivået, og alle elevene i klassen taper på det. Men dersom det er noen få elever med spesialundervisning i klassene, i Markussen m.fl. (2009) beregnet til 2-4 elever i en ordinær yrkesfagklasse på 15 elever, tjente alle på det - i gjennomsnitt. Grøgaard (2002) forklarer dette med at de ekstra ressursene som følger med elevene med spesialundervisning, kommer alle elevene til gode. Han argumenterer også for at det mangfoldet som oppstår med elever med spesialundervisning i klassene, kan representere en berikelse for klassen.

Som nevnt er det også gjennomført to kvalitative studier av spesialundervisning, en under Reform 94 og en under Kunnskapsløftet. I den første ble 48 ungdommer med spesialundervisning fulgt gjennom tre skoleår fra høsten 2000 til våren 2003. Disse ungdommene gikk på seks videregående skoler i to fylker. I den andre ble 15 ungdommer med spesialundervisning fulgt gjennom to skoleår fra høsten 2006 til våren 2008. De gikk på ni forskjellige videregående skoler i tre fylker.

Et viktig funn i den første kvalitative studien, gjennomført under Reform 94, var at det fins ungdommer i videregående opplæring som pga psykososiale vansker eller atferdsvansker, høyst sannsynlig ikke ville makte å være inne i en ordinær klasse. For å mestre tilværelsen, for i det hele tatt å kunne gå på skole og gjøre forsøk på å lære, var disse elevene helt avhengige av å få spesialundervisning utenfor ordinære klasser enten alene eller i små grupper.

Markussen m.fl. (2003) forklarte dette med, basert på hva de unge og deres foreldre fortalte om tiden i barne- og ungdomsskolen, at disse ungdommene 
gjennom hele sin tid i grunnskolen hadde lært at de ikke kunne ha vanlig undervisning, at de ikke kunne være i vanlige klasser, at de var uvanlige, og derfor måtte ha uvanlige opplegg. De hadde lært, at fordi de var som de var, kunne de ikke være i de vanlige klassene, men få spesialundervisning i små grupper eller enetimer. Disse ungdommene måtte bære ansvaret for at systemet hadde sviktet, og ikke hadde vært i stand til å gi dem tilpasset opplæring i tråd med deres individuelle forutsetninger. Dette hadde de lært så grundig gjennom ni år i grunnskolen, at de ikke var i stand til å begynne i videregående opplæring i en ordinær klasse (Markussen m.fl. 2003).

Også den kvalitative studien gjennomført tidlig i Kunnskapsløftet konkluderer på en lignende måte. Grunnskolen svikter noen elever. Ved at de ikke får riktig tilrettelegging og det tilpassede opplæringstilbudet de burde og kunne fått, skapes det et behov for spesialundervisning i videregående opplæring, et behov som for mange av dem sannsynligvis kunne vært unngått. Noen av disse er elever med et stort potensial for læring, men som sannsynligvis fordi forventningene er lave, ikke får faglige utfordringer i grunnskolen. Resultatet er at de går ut av tiende klasse uten karakterer. En indikasjon på at noen av disse elevene har et potensial de ikke har fått utnyttet i grunnskolen, er at vi blant dem observerer noen som presterer godt i videregående opplæring, og får (til dels svært gode) karakterer i vg1. Blant disse er det også elever som har gått ut av grunnskolen uten vurdering i noen fag.

Et annet viktig funn i undersøkelsen fra 2000-2003 var at noen ungdommer med store lærevansker, store sosiale vansker eller store atferdsvansker, og som på mange skoler ville blitt plassert i egne klasser, fikk et tilrettelagt opplegg i ordinære klasser, og klarte seg svært bra. Dette var på skoler der man ut fra en pedagogisk og likeverdsmessig betraktning hadde tatt en beslutning om at hovedlinjen skulle være inkludering av elever med spesialundervisning. Blant de elevene vi fulgte, så vi at når man fulgte denne linjen, oppnådde man ofte resultater; mot alle odds klarte elever seg sosialt og oppnådde også gode faglige resultater. Vi gjorde lignende observasjoner i studien under Kunnskapsløftet. Men vi så også det motsatte, i begge studiene, at for noen elever hvor man forsøkte å gi opplæringen innenfor et klassefellesskap, fungerte ikke dette, og man måtte velge segregerte løsninger. På den andre siden observerte vi også segregerte løsninger som fungerte utmerket for de unge, de hadde utbytte av læringsarbeidet og de fungerte sosialt uten å oppleve stigmatisering. Men vi observerte også segregerte løsninger som ikke fungerte.

Hvis vi skal oppsummere dette kan vi konkludere med at både segregerte og inkluderte opplegg virker, eller de virker ikke. Eller sagt på en annen måte, når vi går bak gjennomsnittstallene, og gjennom kvalitative studier går inn på læringsarenaene, ser vi at det der skjuler seg virkeligheter som de kvantitative undersøkelsene ikke klarer å avdekke, virkeligheter som ser ut til å stå i motsetning til funn fra kvantitative undersøkelser, virkeligheter som gjør at man må foreta en nærmere drøfting av funnene og analysene fra de kvantitative under- 
søkelsene som har konkludert med at elever med spesialundervisning gjør det bedre i ordinære sammenlignet med egne klasser med redusert elevtall.

\section{Drøfting}

Den historiske gjennomgangen foran har vist hvordan politikken for unge med behov for spesialundervisning har utviklet seg fra en tid hvor segregering var løsningen og til i dag hvor målet er at bruken av spesialundervisning skal reduseres og at tilpasset opplæring skal prioriteres innenfor en inkluderende skole. For de som fortsatt skal ha spesialundervisning er målet at de skal få en opplæring som gjør at de kommer lenger enn de ellers ville gjort, at spesialundervisningen skal bidra til å utjevne forskjeller. Slik har det vært siden Reform 94 åpnet portene for all ungdom, og dette ble forsterket og slått fast som et overordnet prinsipp da tilpasset opplæring ble tatt inn i formålsparagrafen i 1998. Kunnskapsløftet betød ingen endring på dette punktet.

Vår gjennomgang av forskning på spesialundervisning i videregående opplæring i perioden 1994-2009 har vist at disse målene i hovedsak ikke nås. Omfanget av spesialundervisning er ikke redusert, og forskningen dokumenterer fortsatt utstrakt bruk av segregerende virkemidler. Kvantitative undersøkelser viser at det er de kunnskaper og ferdigheter elevene har med seg inn i videregående opplæring, målt med grunnskolekarakterer som har sterkest effekt på prestasjoner og kompetanseoppnåelse i videregående opplæring, og at de spesialpedagogiske virkemidlene som settes inn for å kompensere for elevenes skolefaglige vansker og for å øke utbyttet deres, ofte ikke virker etter hensikten. Samtidig viser kvalitative undersøkelser at i noen tilfeller kan segregerende spesialundervisning være riktig vei å gå.

Når vi til tross for 45 års arbeid med å utvikle en inkluderende videregående opplæring, fortsatt har en videregående opplæring som segregerer og som i hovedsak ikke oppnår ønskede resultater, er det grunn til å spørre om det er mulig å komme videre, og hva som kan gjøres. Vi har ikke fasitsvaret på dette spørsmålet, men vil løfte frem et sentralt funn fra de kvalitative studiene vi har referert for å peke på et forhold som etter vår vurdering bør stå helt sentralt.

Vi har vist at konklusjonene fra de kvalitative undersøkelsene til en viss grad modifiserer konklusjonene fra de kvantitative undersøkelsene. Funnene fra de kvalitative studiene viser at segregerende virkemidler kan gi gode resultater i større grad enn konklusjonene fra de kvantitative analysene kan tyde på.

$\mathrm{Vi}$ presiserer at vi ikke anvender funn fra kvalitative undersøkelser for å falsifisere funn fra kvantitative undersøkelser, men de kvalitative analysene gir grunnlag for nyansering og ytterligere refleksjon over funnene fra de kvantitative analysene. Er det slik at de kvalitative studiene viser at det er noe annet som er like viktig for sosial tilpasning og faglig læringsutbytte for elever med spesialundervisning som hvordan opplæringen deres organiseres? Er det slik at distinksjonen innenfor/utenfor likevel ikke er så viktig, men at det er noe 
annet som er like viktig eller kanskje viktigere for at unge med spesialundervisning skal få sosialt og faglig utbytte av læringsarbeidet sitt?

Vi mener at vi gjennom de kvalitative undersøkelsene har identifisert et forhold av sentral betydning, et forhold som kanskje har vel så mye å si for utbyttet av spesialundervisning i videregående opplæring som organisering av denne undervisningen.

Den kvalitative undersøkelsen under Reform 94 konkluderte med at svært viktig for hvordan ungdom med spesialundervisning klarte seg, var det pedagogiske bevissthetsnivået på skolen (at skolens ledelse og personale hadde et gjennomtenkt og bevisst forhold til sin pedagogikk) og at ungdommene fikk tett oppfølging (at de ble sett og fikk nær og individuell, tett oppfølging). Derav rapportens tittel Høy pedagogisk bevissthet og tett oppfølging (Markussen m.fl. 2003).

For å illustrere hva denne pedagogiske bevisstheten innebærer, siterer vi et avsnitt fra nevnte rapport: "Lœeringsarbeidet på denne skolen baserer seg på én pedagogisk grunntanke. Skolen hadde valgt konsekvenspedagogikk som grunnlag for aktiviteten. Alt som skjedde på skolen skulle i prinsippet relateres til konsekvenspedagogikk. Skolens ledelse visste det. Lærerne visste det. Miljøarbeiderne på internatene visste det. Vaktmestere og renholdere visste det. Elevene visste det. Og foreldrene visste det. Konsekvenspedagogikken gjennomsyret virksomheten på denne skolen, og bevissthetsnivået omkring dette var høyt. Alle ansatte ble skolert i konsekvenspedagogisk teori og praksis" Markussen m.fl. (2003:180).

Den kvalitative undersøkelsen under Kunnskapsløftet fant ingen skoler med en tilsvarende helhetlig, gjennomgående pedagogisk grunnfilosofi som lå til grunn for arbeidet med barn og unge med spesialundervisning. Men vi identifiserte én skole som på sin måte hadde en grunnfilosofi og en grunntanke bak sin spesialundervisning.

Vi vil fortelle historiene om Pål og Anne som illustrasjon. Begge hadde mye av undervisningen i grunnskolen alene eller i små grupper, og lærte å lese i sjette-sjuende klasse. De var fritatt for vurdering, og gikk ut av grunnskolen uten karakterer. Begge fullfører vg2 med bestått og var forventet å få læreplass. Anne fikk mye av sin opplæring på denne skolen i ulike små grupper. Hun var fornøyd med det, opplevde ikke stigmatisering og fungert sosialt på skolen. Pål fikk all sin opplæring i klassen sin; han nektet å gå ut i grupper fordi han ville være vanlig og ikke stikke seg ut, og skolen lot ham bestemme dette. Vi ser altså at skolen lykkes med begge disse elevene, den ene med et opplegg med relativt mye segregerte løsninger, den andre inne i klassen sin hele tiden.

Skolen beskrev sin pedagogiske filosofi slik: ”Det betyr at vi ønsker å bringe elevene mest mulig opp mot det ordinære, at en ungdom skal oppleve å være tatt med, å være på linje med alle de andre i forhold til det som skjer rundt elevene. Det er viktig å få være som alle de andre. Men i støtte-gruppa finner de vennene sine. Der trives de stort. Dette kan kalles segregert. Sett utenifra. Men det er på 
elevenes premisser. Fordi vi er vare på å bruke segregerte virkemidler.(...) Men vi er løsningsorienterte. Jeg ser at eleven trives med det. Da går jeg for det”.

Vi ser altså at skolen har en pedagogisk grunnfilosofi, en prinsipiell tenking, som ligger til grunn, men de gir samtidig uttrykk for en pragmatisk praktisering av prinsippene. Og vi ser at dette lykkes. Sammenlignet med den andre skolen omtalt over, vil kanskje enkelte si at her er det ikke en pedagogisk grunnfilosofi som råder, men pragmatismen. Vi vil si at denne skolen også har en pedagogisk bevissthet som ligger i bunnen for det de gjør, men at den er av en annen karakter enn den andre skolen nevnt over.

Hvordan kan vi så konkludere? Et sentralt funn fra våre og andre kvantitative undersøkelser er at elever med spesialundervisning gjør det bedre i ordinære sammenlignet med egne klasser med redusert elevtall. Betyr den drøftingen vi har gjennomført av forholdet mellom de kvantitative og kvalitative funnene at vi må forkaste dette funnet og denne konklusjonen. Svaret på det spørsmålet er nei. Funnet er gjort i flere undersøkelser i løpet av en 15-års-periode, og vi betrakter det som et funn som fortsatt har gyldighet. Funnet er basert på så grundige kvantitative analyser, at det kan danne grunnlag for en klar utdanningspolitisk og pedagogisk anbefaling om å redusere bruken av egne klasser med redusert elevtall som en mye brukt løsning innenfor spesialundervisningen. Men samtidig viser de kvalitative analysene at det fins en annen virkelighet. Derfor vil det fortsatt være situasjoner hvor egne klasser med redusert elevtall kan være den beste løsningen.

De kvalitative analysene peker også i retning av at det er svært avgjørende for om de ulike løsningene gir så gode læringsresultater som mulig for elevene, at man på den enkelte skole blant lærerne som arbeider med elevene til daglig, er tett på elevene og har en høy pedagogisk bevissthet rundt de valgene man tar og rundt den pedagogikken man praktiserer innenfor ulike organisatoriske løsninger; innenfor eller utenfor.

\section{Litteratur}

Ainscow, Mel (1999), Understanding the Development of Inclusive Schools. London: Falmer Press.

Ainscow, Mel (2007), “Towards a more inclusive education system: where next for special schools?” I: Cigman, Ruth (ed.) (2007), Included or Excluded? The challenge of the mainstream for some SEN children. London \& New York: Routledge.

Antia, Shirin D., Michael S. Stinson \& Martha Gonter Gaustad (2002), "Developing membership in the education of deaf and hard-of-hearing students in inclusive settings". Journal of Deaf Studies and Deaf Education, 7: 214-219. I: Mitchell, David (ed.) (2004), Special Educational Needs and Inclusive Education. Major Themes in Education. Volume II, Inclusive Education. London \& New York: Routledge.

Baker, E.T., M.C. Wang \& H.J. Walberg (1994), “The effects of inclusion on learning”. Educational leadership, 52(4), 33-35.

Besl.O. nr. 93 (1992-93), Om endringer i lov 21.juni 1974 nr.55 om videregående opplcering og i lov 23.mai $1980 \mathrm{nr}$ 13. om fagopplaring i arbeidslivet. Oslo 
Besl.O.nr. 68 (1997-98), Lov om grunnskolen og den vidaregåande opplæringa (opplæringslova). Oslo: Stortinget.

Cigman, Ruth (ed.) (2007), Included or Excluded? The challenge of the mainstream for some SEN children. London \& New York: Routledge.

Dunn, Lloyd M. (1968), "Special education for the mildly retarded - is much of it justifiable?" Exceptional Children, 35: 5-22. I: Mitchell, David (ed.) (2004), Special Educational Needs and Inclusive Education. Major Themes in Education. Volume I, Systems and Contexts. London \& New York: Routledge.

Dyson, Alan, Andy Howes \& Barbara Roberts (2003), "What do we really know about inclusive schools? A systematic review of the research evidence”. Paper presented at the AERA Annual Meeting, Chicago, April. I: Mitchell, David (ed.) (2004), Special Educational Needs and Inclusive Education. Major Themes in Education. Volume II, Inclusive Education. London \& New York: Routledge.

Dyson, Alan \& Alan Millward (1997), "The reform of special education or the transformation of mainstream schools?” I: Pijl S.J., C.J.W. Meijer og S. Hegarty, Inclusive Education. London and New York: Routledge.

Fuchs, Douglas \& Lynn S. Fuchs (1994), "Inclusive schools movement and the radicalization of special education reform”. Exceptional Children, 60(4) 294-309. I: Mitchell, David (ed.) (2004), Special Educational Needs and Inclusive Education. Major Themes in Education. Volume II, Inclusive Education. London \& New York: Routledge.

Gartner, Alan \& Dorothy K. Lipsky (1996), “Inclusion, School Restructuring, and the Remaking of American Society.” Harvard Educational Review, 66. Harvard.

Gartner, Alan \& Dorothy K. Lipsky (1999), "Disability, human rights and education: the United States”. I: Armstrong, Felicity og Len Barton (eds.), Disability, human rights and education. Buckingham - Philadelphia: Open University Press.

Grøgaard, Jens B. (2000), Organisatoriske løsninger i videregående opplæring: Fungerer integrering bedre enn segregering? Fafo-notat 2000:4. Oslo: Fafo.

Grøgaard, Jens B. (2002), ”Integrerte eller segregerte undervisningsopplegg i videregående opplæring: Hvilke gir best resultater?” Tidsskrift for Ungdomsforskning 2(2), 83-108.

Grøgaard, Jens B., Ida Hatlevik og Eifred Markussen (2004), Eleven i fokus? En brukerundersøkelse av norsk spesialundervisning etter enkeltvedtak. NIFU STEP rapport 9/2004.

Hallahan, Daniel P. \& James M. Kaufmann (1995), The Illusion of Full Inclusion. A Comprehensive Critique of a Current Special Education Bandwagon. Texas: Pro-ed.

Hausstätter, Rune (2007), Spesialpedagogiske grunnlagsproblemer - mellom ideologi og virkelighet. Bergen, Fagbokforlaget.

Hegarty, Seamus (1989), Meeting Special Needs in Ordinary Schools: An overwiev. London: Casell.

Innst.S. nr. 200 (1991-92), Innstilling fra kirke- og undervisningskomiteen om kunnskap og kyndighet. Om visse sider ved videregående opplæering (St.meld. nr. 33). Oslo.

Innst.O. nr. 80 (1992-93), Innstilling fra kirke- og undervisningskomiteen om lov om endringer i lov av 21.juni 1974 nr. 55 om videregående opplæring og i lov 23.mai 1980 nr. 13 om fagopplæring i arbeidslivet (Ot.prp. nr. 31). Oslo.

Innst. S. nr. 268 (2003-2004), Innstilling fra Kirke-, utdannings- og forskningskomiteen om Kultur for lcering. Oslo: Stortinget.

Jenkinson, Josephine C. (1997), Mainstream or special? Educating students with disabilities. London and New York: Routledge.

Jenssen, E.S. \& Lillejord, S. (2009). Tilpasset opplæring: politisk drakamp om pedagogisk praksis, Acta Didactica Norge, 3(1). Oslo: Universitetet i Oslo.

Kauffmann, James M. \& Gary M. Sasso (2006a), "Toward Ending Cultural and Cognitive Relativism in Special Education”. Exceptionality, 14(2), 65-90. 
Kauffmann, James M. \& Gary M. Sasso (2006b), ”Certainty, Doubt, and the Reduction of Uncertainty”. Exceptionality, 14(2), 109-120.

Kirke- og undervisningsdepartementet (1967), Innstilling I om det videregående skoleverket fra skolekomiteen av 1965. Oslo.

Kirke- og undervisningsdepartementet (1969), Innstilling II om det videregående skoleverket fra skolekomiteen av 1965. Oslo.

Kirke- og undervisningsdepartementet (1970), Innstilling III om det videregående skoleverket fra skolekomiteen av 1965. Oslo.

Kvalsund, Rune og Jon Olav Myklebust (1998), Innestenging, utestenging eller inkludering? Om leringsvilkår, gjennomstrøyming og fråfallsmønster for sœrsvilkårselevar $i$ vidaregåande opplæring. Forskningsrapport nr. 35. Volda: Møreforskning/Høgskulen i Volda.

Kyrkje- og undervisningsdepartementet (1967), Tilråding om Reform av gymnaset fra Utval til å vurdere reform av fagleg innhold og indre oppbygging i gymnaset. Oslo.

Lindsay, Geoff (2003), 'Inclusive education: a critical perspective”. British Journal of Special Education, 30(1): 3-12. I: Mitchell, David (ed.) (2004), Special Educational Needs and Inclusive Education. Major Themes in Education. Volume II, Inclusive Education. London \& New York: Routledge.

Lov om grunnskolen og den vidaregåande opplæringa (opplæringslova). LOV-1998-07-17-61. Sist endret LOV-2008-12-19-188 fra 2009-01-01.

Lov 21.06.74 nr. 55 om videregående opplæring.

Low, Colin (2007), “A defence of moderate inclusion and the end of ideology”. I: Cigman, Ruth (ed.) (2007), Included or Excluded? The challenge of the mainstream for some SEN children. London \& New York: Routledge.

Markussen, Eifred (2000), Scrskilt tilrettelagt opplæring i videregående - hjelper det? Om segregering, inkludering og kompetanseoppnåelse i det første Reform 94-kullet. Fafo-rapport 341. Oslo: Fafo.

Markussen, Eifred (2001), ”Spesialundervisning i videregående - hjelper det?” Norsk pedagogisk tidsskrift, 2001(5), 467-486. Universitetsforlaget Oslo.

Markussen, Eifred (2004), "Special education: does it help? A study of special education in Norwegian upper secondary schools”. European Journal of Special Needs Education. 19(1), 2004. Routledge, London.

Markussen, Eifred, Synnøve Brandt og Ida Hatlevik, (2003), Høy pedagogisk bevissthet og tett oppfølging. Om sammenheng mellom pedagogikk og faglig og sosial utbytte av videregående opplcering for elever med spesialundervisning. NIFU rapport 5/2003.

Markussen, Eifred, Mari Wigum Frøseth og Jens B. Grøgaard (2009), Inkludert eller segregert? Om spesialundervisning i videregående opplæring like etter innføringen av Kunnskapsløftet. Rapport 17-2009. Oslo: NIFU STEP.

Mitchell, David (2004), “Introduction”. I: Mitchell, David (red.) (2004), Special Educational Needs and Inclusive Education. Major Themes in Education. Volume II, Inclusive Education. London \& New York. Routledge.

Nordahl, Thomas og Anne-Karin Sunnevåg (2008), Spesialundervisning i grunnskolen - stor avstand mellom idealer og realiteter. Høgskolen i Hedmark, Rapport nr. 2 - 2008.

Norwich, Brahm (2007), "Dilemmas of inclusion and the future of education”. I: Cigman, Ruth (ed.) (2007), Included or Excluded? The challenge of the mainstream for some SEN children. London \& New York: Routledge.

NOU 1991:4, Veien videre til studie- og yrkeskompetanse for alle. Oslo: Kirke-, utdannings- og forskningsdepartementet.

NOU 1995: 18, Ny lovgivning om opplering. "... og for øvrige kan man gjøre som man vil”. Oslo: Kirke-, utdannings- og forskningsdepartementet.

NOU 2003: 16, I første rekke. Forsterket kvalitet i grunnopplering for alle. Oslo: Kirke-, utdannings- og forskningsdepartementet.

NOU 2009: 18, Rett til læring. Oslo: Kunnskapsdepartementet. 
OECD (1999), Inclusive education at Work. Students with disabilities in mainstream schools. OECD.

Ot.prp. nr. 31 (1992-93), Om lov om endring i lov 21.juni 1974 nr. 55 om videregående opplering og i lov 23.mai 1980 nr. 13 om fagopplcering i arbeidslivet. Oslo: Kirke-, utdannings- og forskningsdepartementet

Ot. prp. nr. 57 (2004-2005), Om lov om endringar i opplceringslova og friskolelova. Oslo: Utdannings- og forskningsdepartementet.

Salend, Spencer J. \& Laurel M. Garrick Duhaney (1999), “The impact of inclusion on students with and without disabilities and their educators”. Remedial and Special Education, 20(2), 114-26. I: Mitchell, David (ed.) (2004), Special Educational Needs and Inclusive Education. Major Themes in Education. Volume IV, Effective Practices. London \& New York: Routledge.

Skrtic, Thomas M. (1991), Behind special education: a critical analysis of professional culture and school organization. Denver: Love Publishing Company.

Skrtic, Thomas M., Wayne Sailor \& Kathleen Gee (1996), "Voice, collaboration, and inclusion: democratic themes in educational and social reform initiatives". Remedial and Special Education, 17(3), 142-57. I: Mitchell, David (ed.) (2004), Special Educational Needs and Inclusive Education. Major Themes in Education. Volume II, Inclusive Education. London \& New York: Routledge.

Staub, D. og C.A. Peck (1994), "What are the outcomes for nondisabled students?” Educational leadership, 52(4), 36-40.

St.meld. nr. 42 (1965-66), Om utbygging av spesialskolene. Oslo: Kirke- og undervisningsdepartementet.

St.meld. nr. 91 (1969-70), Om reform av gymnaset og forsøk med utbygging av det videregående skoleverk. Oslo: Kirke- og undervisningsdepartementet.

St.meld. nr. 33 (1991-92), Kunnskap og kyndighet. Om visse sider ved videregående opplcring. Oslo: Kirke-, utdannings- og forskningsdepartementet.

St.meld. nr. 30 (2003-2004), Kultur for laring. Oslo: Utdannings- og forskningsdepartementet. Topping, Keith \& Sheelagh Maloney (2005), ”Introduction”. I Topping, Keith \& Sheelagh Maloney (eds.) (2005), The RoutledgeFalmer Reader in Inclusive Education. New York: RouteledgeFalmer.

Aarnes, Arne (1987), Rett retrett, Om skoleretten som ble retten til å stå på venteliste. Oslo: NKSforlaget.

\footnotetext{
${ }^{1}$ Jeg har i perioden 1994-2009 gjennomført flere forskningsprosjekter innenfor spesialundervisning i videregående opplæring alene eller i samarbeid med andre. Denne artikkelen bygger i stor grad på disse tidligere arbeidene (Markussen 2000, Markussen m.fl. 2003 og Markussen m.fl. 2009), men viser også til andre arbeider. Jeg har også tidligere skrevet artikler om temaet i ulike sammenhenger, sist artikkelen "Spesialundervisning i videregående virker ikke etter intensjonen - uendret etter Kunnskapsløftet” i boken Videregående opplcering for (nesten) alle (Markussen (red.) 2009). At jeg har behandlet temaet skriftlig så mange ganger tidligere betyr også at noe av innholdet vil ligne på tidligere publisert tekst. Oppbygningen og det helhetlige resonnementet er imidlertid nytt, og tolkningene og drøftingene til slutt i artikkelen peker hen mot andre konklusjoner enn tidligere. Det foreliggende arbeid kan derfor betraktes som "work in progress", et arbeid hvor tidligere tolkninger og drøftinger utfordres og videreutvikles.

${ }^{2}$ Vi kjenner selvsagt til at det har foregått og fortsatt foregår debatt om spesialundervisningen, særlig med utgangspunkt i Midtlyngutvalgets innstilling, NOU:2009:18 Rett til lcering. Her omtales ikke denne, da forskningsarbeidene som ligger til grunn for denne artikkelen alle var ferdigstilt da Midtlyngutvalget leverte sin innstilling. Det som omtales i denne artikkelen ligger derfor forut for Midtlyngutvalgets ferdige innstilling i tid.

${ }^{3}$ Bortsett fra at ordene ”for barn, unge og vaksne”, ble strøket i paragrafens tittel.
} 